\title{
Evaluation of cytotoxic effect of ferrous gluconate on Allium cepa root tip
}

\author{
Ferro glukonatın sitotoksik etkisinin Allium cepa kök ucunda dĕgerlendirilmesi
}

\author{
Nergis KAYA ${ }^{* 1, a}$ \\ ${ }^{I}$ Çanakkale Onsekiz Mart University, Biga Vocational School, Food Processing Department, Food Technology Program, Biga, \\ 17200, Çanakkale, Turkey
}

• Geliş tarihi / Received: 20.12.2020 • • Düzeltilerek geliş tarihi / Received in revised form: 17.04.2021 • Kabul tarihi / Accepted: 21.04 .2021

\begin{abstract}
It was used Allium cepa L and ferrous gluconate (E579). A. cepa roots were treated with ferrous gluconate of different concentrations. A. cepa root lengths were measured. So, the EC50 value was determined as $0.068 \mathrm{~g} / \mathrm{l}$. Then, A. cepa L. roots were treated with EC50 / 2 (0.034 g/l), EC50 (0.068 g/l), 2XEC50 (0.136 g/l) for 24, 48, 72 hours. The root tips were cut and prepared for observation in the light microscope. For each group, at least 5000 cell counts were made. Mitotic index was used in the determination of cytotoxicity. TUKEY multiple comparison test and Repeated measurement ANOVA was used. It was determined that the difference between ferrous gluconate concentrations varied as far as the treatment duration. In the way of mitotic index, it was stated that mean of control doses at all treatment duration were significantly higher than the EC50/2, EC50, EC50X2 doses and decreased with the increasing dose. After 24, 48 and 72 hours treatment of EC50X2 dose, it was found that mitotic index decreased due to increasing in application duration. It was detected that ferrous gluconate reduced mitotic division at the root of $A$. cepa in comparison to the control group. In this way, it was established that ferrous gluconate can be cytotoxic. In addition to this, it was determined that the cytotoxic effect of ferrous gluconate increased and mitotic index decreased due to increasing of treatment duration and dose. Results of this research are parallel with the literatüre that food additives might cause cytotoxicity.
\end{abstract}

Keywords: Allium cepa test, Cytotoxicity, Ferrous gluconate

$\ddot{O} z$

Araştırmada, Allium cepa L ve ferro glukonat (E579) kullanılmıştır. A. cepa kökleri, farklı konsantrasyonlarda ferro glukonat ile muamele edilmiştir. A. cepa kök uzunlukları ölçülmüştür. Böylece EC 5 değeri 0,068 g / l olarak belirlenmiştir. Daha sonra A. cepa kökleri 24, 48, 72 saat EC $C_{50} / 2(0.034 \mathrm{~g} / \mathrm{l}), E C_{50}(0.068 \mathrm{~g} / \mathrm{l}), 2 \mathrm{XEC}_{50}(0.136 \mathrm{~g} / \mathrm{l})$ ile muamele edilmiştir. Bu sürelerin sonunda kök uçları kesilerek ışık mikroskobunda gözlem için hazırlanmıştır. Her muamele periyodu ve konsantrasyon için en az 5000 hücre sayılmıştır. Sitotoksisitenin belirlenmesinde mitotik indeks kullanılmıştır. Mitotik indeks (MI) = bölünen hücre sayısı / toplam hücre sayısı X 100 formülü ile hesaplanmıştır. TUKEY çoklu karşılaştırma testi ve tekrarlanan ölçümlü ANOVA kullanılmıştır. Ferro glukonat konsantrasyonları arasındaki farkın muamele süresine göre değişstiği belirlenmiştir. Mitotik indeks açısından, tüm uygulama periyodu sonunda kontrol dozlarının ortalamasının $E C_{50} / 2, E C_{50}, E C_{50} X 2$ dozlarına göre yüksek olduğu bulunmuştur ve artan dozla azaldığı ortaya konmuştur. EC $C_{50} X 2$ konsantrasyonunun 24, 48 ve 72 saat süresince muamelesinin ardından, muamele süresi uzadıkça mitotik indeksin azalmış olduğu saptanmıştır. Kontrol grubuna göre ferro glukonatın kök uçlarında hücre bölünmesini azalttı̆̆ bulunmuştur. Böylece, ferro glukonatın A. cepa kök uçlarında sitotoksik olduğu ortaya konmuştur. Ayrıca, muamele süresi ve dozunun artması nedeniyle ferro glukonatın sitotoksik etkisinin arttığ ve bunun nedeninin de mitotik indeksin azaldı̆̆ından dolayı olduğu saptanmıştır. Araştırma sonuçları, literatürdeki gıda katkı maddelerinin sitotoksik etkisinin olabileceğinin saptanması sonuçlarıla paralellik göstermektedir.

Anahtar kelimeler: Allium cepa test, Sitotoksisite, Ferro glukonat

\footnotetext{
*a Nergis KAYA; nergiskaya@ comu.edu.tr, Tel: (0286) 31628 78, orcid.org/0000-0002-4206-1149
} 


\section{Introduction}

It is necessary to find new food resources against the increasing world population every year and to protect them for a long time without deterioration (Rencüzoğulları et al., 2001; Kayraldız and Topaktaş, 2007). Food additives are the most striking group of chemical substances used for various purposes. These substances are generally defined as "substances used to affect the properties of foods in the desired way" (Altug et al., 2000). Although natural additives are used, with the development of technology in recent years, artificial additives that accelerate the production and reduce the costs have been used (Gürsoy, 2001). When food additives are used indiscriminately and out of regulation, they may cause allergic and toxic reactions among consumers (Arslan, 2004). Even if the food additives used are used in amounts that do not harm health, it is an important issue to consider that these substances may accumulate in the body over time and cause tissue damage, thus directly or indirectly threatening human health. Because of this risk, the toxic effects of various substances, including food additives, are investigated by in vivo tests.

The resulting surface color of black olives is not permanent, it gradually disappears after oxidation and throughout the life of the packaged product. Iron salts (ferrous gluconate, ferrous sulphate, ferrous lactate) are used to prevent this degradation (Cruess, 1962). Of these, ferrous gluconate is a food additive that dissolves well in water (Hurrell, 1997). Ferrous gluconate (E579) consists of food additive, iron and glucose. This food additive is used to preserve the black color after the thickening step in mature black olives to prevent discoloration during storage (Garcia et al., 1986; Anonymous, 1995). Plant test systems are widely used in the assessment of possible toxicity caused by environmental pollutants and different chemical substances. Additionally, due to the meristematic nature of plant roots, it is suitable for determining cytotoxicity (Fiskesjö, 1985; Ma et al., 1996). Tests made with plants have high sensitivity (Grant, 1978). The test is important because it is an in vivo model whose cytotoxicity grows in direct interaction with the substance under investigation and can assess damage to eukaryotes DNA. Therefore, data can be accurately evaluated for all animal and plant biodiversity. The sample must remain in a constant phase of mitotic division by trying to identify toxic effects and changes on a cell cycle, and the test is widely used for this purpose (Tedesco and Laughinghouse, 2012). Cytogenetic factors such as mitotic index and chromosome abnormalities in root tip cells of onion (Allium cepa L.) are the parameters used to determine the toxic effect (Özkara et al., 2015). Since A. cepa has a low number of chromosomes $(2 \mathrm{n}=16)$ and is large in terms of structure, it is easy to examine under the microscope. Onions are inexpensive and easy to obtain as they can be grown any time of the year (Ak1 and Çördük, 2011). The meristematic cells of the roots of A. cepa have kinetic properties of proliferation and a low number of chromosomes, resulting in its reliability and compatibility with other toxicological tests using higher eukaryotic test systems (Tabrez et al., 2011). For these reasons, A. cepa was chosen as the test material in this research. In parallel with this research, there are also studies about the cytotoxic effect of food additives in A. cepa root tips using by the Allium cepa test are available in the literature (Lerda, 2017; Oliveira et al., 2017; Moura et al., 2016; Marques et al., 2015a). It has been stated that the analyzes made with plants are very sensitive to evaluate the cytotoxic effect of food additives (Iganci et al., 2006). There are a lot of higher plants. For example, Vicia faba, Tradescantia, Hordeum vulgare, and A. cepa that can be used to analyze for cytogenetic effects of chemicals (Misik et al., 2006; Sang and Li, 2004). Among these, the Allium test is the best test system to assess toxicity (Fiskesjö, 1997; Liman et al., 2010; Türkoğlu, 2008). Allium test is used as an alternative model to mammalian test systems for cytogenotoxicity studies. It is stated that the results of studies with Allium test and food additives are valid when compared with the results of previous studies on mammalian tests. It was stated that A. серa has been used to evaluate DNA damage in the mitotic cycle (Türkoğlu, 2013).

Mitotic index (MI) is accepted as a criterion for determining cytotoxicity for all living organisms (Amer and Aly, 1992). The cytotoxic level can be determined by changes in the mitotic index ratio (Linnainmaa et al., 1978; Smaka-Kincl et al., 1996). Cytotoxic substances show their effects on mitosis by inhibiting microtubule formation (Amer and Ali, 1974).

In the study, it was aimed to determine the cytotoxicity caused by the root tip cells of the $A$. cepa $\mathrm{L} .(2 \mathrm{n}=16)$ species of ferrous gluconate food additive in the cycle of mitosis. For this purpose, ferrous gluconate was applied to the root tips of $A$. сера at different concentrations and different durations. In determining cytotoxicity, the mitotic index was calculated by determining the number of cells in mitosis and the total number of cells. In the literature searches, no cytotoxicity study that can 
be caused by ferrous gluconate was found in any plant, animal and human tests. The research completed with this aspect is considered to be original.

\section{Material and method}

\subsection{Material}

Allium cepa L. was used. Ferrous gluconate (E579), purchased from Cesa Chemical Ind. Trade Ltd. Co., used.

\subsection{Method}

\subsubsection{Treatment with EC $C_{50}$ values}

$\mathrm{EC}_{50}$ value $(0.068 \mathrm{~g} / 1)$ was determined by treating A. cepa $\mathrm{L}$. root tips with different concentrations of ferrous gluconate (Fiskesjö, 1993). A. cepa root tips were treated with concentrations of $\mathrm{EC}_{50} / 2$ (0.034 g / 1), $\mathrm{EC}_{50}(0.068 \mathrm{~g} / \mathrm{l}), 2 \mathrm{XEC}_{50}(0.136 \mathrm{~g} /$ 1) for $24 \mathrm{~h}, 48 \mathrm{~h}, 72 \mathrm{~h}$.

\subsubsection{Preparation of slides}

The root tips were cut and treated as expressed by Souguir et al., 2008. Root tips were hydrolyzed with $\mathrm{HCl}$ at $60^{\circ} \mathrm{C}$ for 10 minutes. The samples were prepared and stained in $\% 2$ acetocarmine $(\mathrm{w}$ / v). It was counted 1000 cells for each group. For each group, at least 5 slides (at least 5000 cells) were prepared. Root tips were estimated by detecting mitotic cells with a light microscope with a 1000X objective.

\subsubsection{Assessing of cytotoxicity}

Cytotoxicity was assessed by determining the mitotic index (MI). Calculated with the formula MI $=$ Number of cells divided $/$ Total number of cells $\mathrm{X} 100$. The mitotic index is generally considered to be the number of mitoses per 100 cells. In this study, at least 1000 cells were counted for application group in the examinations under light microscope. Mitotic index (MI) was calculated by determining the cells undergoing mitosis within 1000 cells and their stages of division.

\subsubsection{Statistical analysis}

The effect of time and dose on cytotoxicity properties, TUKEY and repeated measure ANOVA was used

\section{Results and discussion}

In terms of mitotic index, the mean of control doses at the end of 24, 48 and 72 hours of treatment was significantly higher than the $\mathrm{EC}_{50} / 2, \mathrm{EC}_{50}, \mathrm{EC}_{50} \mathrm{X} 2$ doses. When ferrous gluconate was applied for 24 hours, it was determined that the mitotic index was the highest in the control group and decreased with increasing dose. When administered for 48 and 72 hours, it was found that the mitotic index was the highest in the control group, but no statistically important difference was found between the other doses. In terms of mitotic index, averages were found to be the lowest at EC50, EC50X2 doses. It was determined that the EC50 / 2 and EC50 doses were treated for 24 hours and the mitotic index was statistically higher than the 48 and 72 hours treatment. As a result of the application of EC50 / 2 and EC50 doses for 48 and 72 hours, it was found that there was no statistically significant change in the mitotic index due to the increasing in application time. As a result of the treatment of EC50X2 dose for 24, 48 and $72 \mathrm{~h}$, it was detected that the mitotic index decreased statistically due to the increase in application time. In this way, it has been determined that ferrous gluconate has a cytotoxic effect. It was determined that the cytotoxic effect increased depending on the treatment time and concentration increase, and the mitotic index decreased depending on the application period and concentration increase. Compared to the control group, ferrous gluconate was found to reduce mitosis in A. cepa root tips (Table 1).

Mitotic phases (prophase, metaphase, anaphase, telophase) were administered after the application of ferrous gluconate at EC50 / 2, EC50 and EC50X2 doses to the root tips of A. cepa for 24, 48 and 72 hours. In addition, a statistical study was conducted by giving \% mitotix index averages and standard errors (Table 1).

It has been revealed that orange $\mathrm{G}$ and brilliant blue (Kumar and Singh, 2017), sweeteners passion fruit and vanilla (Nunes et al., 2017) have a cytotoxic effect. Lerda (2017) found that tartrazine was decreased the mitotic index depending on the incereasing concentration and the increasing treatment time in root tip cells. Parallel with this study and this researh results, Oliveira et al. (2017) indicated that sodium saccharin and sodium cyclamate sweeteners in root tip cells was decreased mitotic index depending on treatment time. 
Table 1. Mitotic phases and mitotix index

\begin{tabular}{|c|c|c|c|c|c|c|}
\hline \multirow[t]{2}{*}{ Treatment time (h) } & \multirow[t]{2}{*}{ Concentration (g/l) } & \multicolumn{4}{|c|}{ Mitotic phases (\%) } & \multirow{2}{*}{$\begin{array}{l}\text { \%Mitotic index } \\
\text { (mean } \pm \text { std. error) }\end{array}$} \\
\hline & & Prophase & Metaphase & Anaphase & Telophase & \\
\hline \multirow{4}{*}{24} & Control & 45.86 & 21.19 & 17.35 & 14.12 & $16.57 \pm 1.03 \mathrm{Aa}$ \\
\hline & $\mathrm{EC}_{50} / 2$ & 49.59 & 23.40 & 12.20 & 10.02 & $12.138 \pm 0.83 \mathrm{Ba}$ \\
\hline & $\mathrm{EC}_{50}$ & 53.30 & 22.23 & 12.45 & 10.81 & $9.097 \pm 0.139 \mathrm{Ca}$ \\
\hline & $\mathrm{EC}_{50} \mathrm{X} 2$ & 52.58 & 26.22 & 16.28 & 8.11 & $8.107 \pm 0.346 \mathrm{Da}$ \\
\hline \multirow{4}{*}{48} & Control & 39.90 & 22.20 & 19.72 & 17.23 & $17.051 \pm 0.602 \mathrm{Aa}$ \\
\hline & $\mathrm{EC}_{50} / 2$ & 47.33 & 29.14 & 12.81 & 10.40 & $6.474 \pm 0.377 \mathrm{Bb}$ \\
\hline & $\mathrm{EC}_{50}$ & 44.90 & 29.92 & 14.85 & 14.51 & $5.916 \pm 0.28 \mathrm{Bb}$ \\
\hline & $\mathrm{EC}_{50} \mathrm{X} 2$ & 43.14 & 28.07 & 16.61 & 11.86 & $5.527 \pm 0.132 \mathrm{Bb}$ \\
\hline \multirow{4}{*}{72} & Control & 46.83 & 19.64 & 17.54 & 16.43 & $15.876 \pm 0.472 \mathrm{Aa}$ \\
\hline & $\mathrm{EC}_{50} / 2$ & 44.30 & 30.11 & 15.22 & 11.57 & $4.9042 \pm 0.0676 \mathrm{Bb}$ \\
\hline & $\mathrm{EC}_{50}$ & 49.96 & 28.65 & 13.53 & 13.18 & $4.469 \pm 0.613 \mathrm{Bb}$ \\
\hline & $\mathrm{EC}_{50} \mathrm{X} 2$ & 26.88 & 27.64 & 29.87 & 15.69 & $3.325 \pm 0.312 \mathrm{Bc}$ \\
\hline
\end{tabular}

Note 1. Difference between concentrations in different capitals for the same application period is important

Note 2. Difference between application period at the same dose, shown in different lowercase letters, is important

Sales et al. (2016) found that the doses of two artificial synthetic food sweeteners and the combined doses were cytotoxic in A. cepa root tips. It was determined that the tutti-frutti aroma had no cytotoxic effect. Contrary to this, it was determined that ferrous gluconate has a cytotoxic effect in this reserch. Moura et al. (2016) determined that when two synthetic food additives were applied for 24 and 48 hours, it reduced cell division rates. For this reason, it has been assessed that both food additives are cytotoxic. It has been indicated that sunset yellow, brilliant blue (Kuş and Eroğlu, 2015) and Ponceau 4R (Marques et al., 2015b) have a cytotoxic effect. Marques et al. (2015a) treated root tips with food sweeteners fors 24 and 48 hours and stated that these sweeteners have cytotoxic effects. It was indicated that sunset yellow (Dwivedi and Kumar, 2015); benzoate and boric acid (Kumar and Pandey, 2015) has cytotoxic effect. When root tips were treated with food preservatives such as butylated hydroxytoluene, butylated hydroxyanisole, sorbic acid, propyl gallate and sodium nitrate (Pandey et al., 2014), it was determined that the mitotic index decreased with increasing concentration. It has been demonstrated that tartrazine and sunset yellow (Dwivedi and Kumar, 2017); monosodium glutamate (Adeyemo and Farinmade, 2013); sunset yellow, tartrazine (Gomes and Oliveira, 2013); monosodium glutamate, monopotassium glutamate, calcium glutamate, monoammonium glutamate, magnesium diglutamate (Türkoğlu, 2013); potassium metabisulfite and potassium nitrate (Gömürgen, 2005) have an inhibitory effect on root tip cell division and cause a decrease in mitotic index values. In this way, it has been indicated that these food additives have cytotoxic effects. Thus, these have an inhibitory impact on mitotic division. In parallel with these studies, it was evaluated that increasing concentrations of ferrous gluconate and increasing treatment time decreased the mitotic index.

Cytotoxicity is largely due to chromosome changes resulting from modifications of bases in DNA or other disorders in DNA. A reduction in the mitotic index reflects an inhibition of the cell cycle and a loss of cell proliferation capacity. In addition to this, Allium cepa test provide important information about the mechanism of action of some chemicals in cells (Rojas et al., 1993; Anderson et al., 1988).

\section{Conclusion}

In the result of research, it was determined that ferrous gluconate caused cytotoxicity in A. cepa when exposed to more than specific concentrations and durations. This effect is shown by inhibiting mitosis. So, it was assessed that ferrous gluconate was decreased the mitotic index. The results of the cytotoxic effect of ferrous gluconate determined in A. cepa can be a prestudy for animal and human researches that can be done with ferrous gluconate.

\section{Acknowledgement}

This research project which numbered as FBA2018-1443 was supported by Canakkale Onsekiz Mart University Commission of Scientific Research Projects. 


\section{References}

Adeyemo, O.A. and Farinmade, A. E. (2013). Genotoxic and cytotoxic effects of food flavor enhancer, monosodium glutamate (MSG) using Allium cepa assay. African Journal of Biotechnology, 12(13), 1459-1466. https://doi.org/ 10.5897/AJB12.2927

Akı, C. and Çördük N. (2011). Genetik laboratuvar kılavuzu, Kriter Yayınları, İstanbul.

Altuğ, T., Boyacioğlu, D., Kurtcan, Ü. and Demirağ, K. (2000) Glda katkı maddeleri analiz yöntemleri, Ege Üniversitesi Mühendislik Fakültesi Yayınları, Ege Üniversitesi Basımevi, Bornova, İzmir.

Amer, S.M. and Ali, E. M. (1974). Cytological effects of pesticides V. Effects of some herbicides on Vicia faba. Cytologia, 39, 633-643.

Amer S.M. and Aly, F.A. (1992). Cytogenetic Effects of Pesticides. IV. Cytogenetic effects of the insecticides gardona and dursban. Mutation Research, 279(3), 165-170. https://doi.org/10.1016/0165-1218(92)90063-6

Anderson, D., Jenkinson, P.C., Dewdeney, R.S., Franis, A.J., Godbert, P. and Butterworth, K.R. (1988). Chromosome aberrations, mitogen-induced blastogenesis and proliferative rate index in peripheral lymphocytes from 106 control individuals of U.K. population. Mutation Research/Genetic Toxicology 204(3), 407-20. https://doi.org/10.1016/0165-1218(88)90150-4

Anonymous. (1995). Code of Federal Regulations. Office of the federal register national archives and records administration, Washington, DC.

Arslan, M. and Rencüzoğulları, E. (2004). Borik asit'in insan periferal lenfositlerinde in vitro kromozom aberasyonu ve kardeş kromatid değişimi üzerindeki etkileri. Science Institute, Cukurova University, Adana, 2004.

Cruess, W. V. (1962). Experiments on color fixation with iron salts, in 41 Annual Technical Report of California Olive Association, Sacramento, CA.

Dwivedi, H. and Kumar, G. (2017). Genomic distortion induced by food dyes on meristematic cells of Trachyspermum ammi (L.) Sprague (Ajwain). Chromosome Botany, 12(3), 46-51. https://doi.org/10.3199/iscb.12.46

Dwivedi, K. and Kumar, G. (2015). Genetic damage induced by a food coloring dye (sunset yellow) on meristematic cells of Brassica campestris L. Journal of Environmental and Public Health, 2015, 1-5. https://doi.org/10.1155/2015/319727
Fiskesjö, G. (1993). The Allium cepa test in wastewater monitoring. Environmental Toxicology \& Water Quality, 8(3), 291-298. https://doi.org/10.1002/tox.2530080306

Fiskesjö, G. (1985). The Allium-test as a standard in environmental monitoring, Hereditas, 102, 99112. https://doi.org/10.1111/j.16015223.1985.tb00471.x

Fiskesjö, G. (1997) Allium test for screening chemicals; evaluation of cytological parameters. Ln: Wang W, Gorsuch JW and Hughes JS (Eds) Plants for Environmental Studies. New York, NY: Lewis Publishers, pp. 308-333. https://doi.org/10.1201/9781420048711.ch11

Garcia, P., Brenes, M. and Garrido, A. (1986). Use of ferrous lactate in the elaboration of ripe olives. Grasas Aceites, 37, 33-38.

Gomes, K. M. S. and Oliveira, M. V. G. A. (2013). Citotoxicity of food dyes sunset yellow (E-110), bordeaux red (E-123), and tatrazine yellow (E102) on Allium cepa L. root meristematic cells. Food Science and Technology, Campinas, 33(1), 218-223. 20612013005000012

Gömürgen, A. N. (2005). Cytological effect of the potassium metabisulphite and potassium nitrate food preservative on root tips of Allium cepa $\mathrm{L}$. $\begin{array}{llll}\text { Cytologia, } & 70 & \text { (2), } & 119-128 .\end{array}$ https://doi.org/10.1508/cytologia.70.119

Grant, W. F. (1978). Chromosome aberrations in plants as a monitoring system. Environmental Health Perspectives, 27, 37-43. https://doi.org/10.1289/ehp.782737

Gürsoy, S. ve Aktaç, T. (2001). Besinlerde katkı maddelerinin kullanımı ve sitrik asit toksisitesi, Yüksek Lisans Tezi, Trakya Üniversitesi Fen Bilimleri Enstitüsü, Tekirdağ.

Hurrell, R. F (1997). Preventing iron deficiency through food fortification. Nutrition Reviews, 55(6), 210222 . https://doi.org/10.1111/j.17534887.1997.tb01608.x

Iganci, J.R.V, Bobrowski, V.L., Heiden, G., Stein, V.C. and Rocha, B.H.G. (2006). Efeito do extrato aquoso de diferentes espécies de boldo sobre a germinação e índice mitótico de Allium cepa L. Arquivos do Instituto Biológico 73, 79-82.

Kayraldız, A. and Topaktaş, M. (2007). The in vivo genotoxic effects of sodium metabisulfite in bone marrow cells of rats. Russian journal of genetics, 43(8), 905- 909. https://doi.org/10.1134/s1022795407080121

Kumar G. and Pandey A. (2015). Genotoxic and mitodepressive effects of food preservatives on root 
meristems of barley (Hordeum vulgare L.). Chromosome Botany, 10: 51-60. https://doi.org/10.3199/iscb.10.51

Kumar, G. and Singh, S. (2017). Genotoxic effects of food dyes on mitotic chromosomal entity in root meristems of Cluster bean (Cyamopsis tetragonoloba (L.) Taub.). International Journal of ChemTech Research, 10(13), 81-89.

Kuş, E. and Eroğlu, H. E (2015). Genotoxic and cytotoxic effects of sunset yellow and brilliant blue, colorant food additives, on human blood lymphocytes. Pakistan Journal of Pharmaceutical Sciences 28(1), 227-30.

Lerda, D. (2017). The effects of tartrazine in Allium cepa L. Journal of Food Nutrition, 3(101), 1-5. https://doi.org/10.17303/jfn.2017.3.101

Linnainmaa, K., Meretoja, T., Sorsa, M. and Vainto, H. (1978). Cytogenetic effects of styrene and styrene oxide. Mutation Research/Genetic Toxicology, 58, 277-286. https://doi.org/10.1016/0165-1218(78)90020-4

Liman, R., Aky1l, D., Eren, Y. and Konuk, M. (2010) Testing of mutagenicity and genotoxicity of metolcarb by using both Ames/Salmonella and Allium test. Chemosphere, 80:1056-1061. https://doi.org/10.1016/j.chemosphere.2010.05. 011

Ma, T. H., Xu, C., Liao, S., McConnell H., Jeong, B. S. and Won C. D. (1996). In Situ monitoring with the tradescantia bioassays on the genotoxicity of gaseous Emissions from a closed landfill site and an incinerator. Mutation Research/Environmental Mutagenesis and Related Subjects, 359, 39-52. https://doi.org/10.1016/s0165-1161(96)90008-4

Marques, G. S. and Silva S. O., (2015b). Cytotoxic and genotoxic potential of liquid synthetic food flavorings evaluated alone and in combination. Food Science Technology, Campinas, 35(1), 183-188. https://doi.org/10.1590/1678$457 \times .6596$

Marques, G. S., Sousa, J. J. A. and Peron, A. P. (2015a). Action of ponceau $4 \mathrm{R}$ (E-124) food dye on root meristematic cells of Allium cepa L. Acta Scientiarum. Biological Science, 37(1), 101-106. https://doi.org/10.4025/actascibiolsci.v37i1.231 19

Misik, M., Solenska, K., Micieta, K., Misikova, K. and Knasmüler S. (2006). In situ monitoring of mutagenic effects of contamj-nated air in Bratislava (Slovakia) with Tradescantia micronucleus (Trad-MCN) and abortive microspore assays. Mutation Research, 605: 1-6.
Moura, A. G., Santana, G. M., Ferreirab, P. M. P, Sousaa, J. M. C and Peron, A. P. (2016). Cytotoxicity of cheese and cheddar cheese food flavorings on Allim cepa $\mathrm{L}$ root meristems. Brazilian Journal of Biology, 76(2), 439-443. https://doi.org/10.1590/1519-6984.20514

Nunes, R. D. M., Sales, I. M. S., Silva, S. I. O., Sousa, J. M. C. and Peron, A. P. (2017). Antiproliferative and genotoxic effects of nature identical and artificial synthetic food additives of aroma and flavor. Brazilian Journal of Biology, 77(1), 150-154. https://doi.org/10.1590/15196984.12115

Oliveira, V. A., Oliveira, V. M., Oliveira, T. W. N., Damasceno, A. N. C., Silva, C. E. O., Medeiros, S. R. A., Soares, B. M., Silva, F. C. C., Aguiar, R. P. S., Islam, M. T., MeloCavalcante, A. A. C., Peron, A. P. and Sousa, J. M. C. (2017). Evaluation of cytotoxic and mutagenic effects of two artificial sweeteners by using eukaryotic test systems. African Journal of Biotechnology, 16(11), 547-551. https://doi.org/10.5897/ajb2016.15695

Özkara, A., Akyil, D., Eren, Y., Erdogmus, S. F., Konuk, M. and Saglam, E. (2015). Assessment of cytotoxic and genotoxic potential of pyracarbolid by Allium test and micronucleus assay. Drug and Chemical Toxicology, 38(3), 337-341. https://doi.org/10.3109/01480545.2014.966831

Pandey, H., Vikas Kumar, V. and Roy, B. K. (2014). Assessment of genotoxicity of some common food preservatives using Allium cepa $\mathrm{L}$. as a test plant. Toxicology Reports, 1, 300-308. https://doi.org/10.1016/j.toxrep.2014.06.002

Rencuzogulları, E., Kayraldız, A., Ila, H. B., Çakmak, T. and Topaktaş, M. (2001). The cytogenetic effects of sodium metabisulfite, a food preservative in root tip cells of Allium cepa L. Turkish Journal of Biology, 25, 361-370.

Rojas, E, Herrera, L A, Sordo, M, Gonsebatt, M E, Montero, R, Rodriguez, R. and OstroskyWegman, P. (1993). Mitotic index and cell proliferation kinetics for the identification of antineoplastic activity. Anti-Cancer Drugs. 4(6), 637-40. https://doi.org/10.1097/00001813199312000-00005

Sales, I. M. S., Oliveira, J. D., Santos, F. K. S., Feitoza, L. L., Sousa, J. M. C. and Peron, A. P. (2016). Toxicity at the cellular level of artificial synthetic flavorings. Acta Scientiarum. Biological Sciences, 38(3), 297-303. https://doi.org/10.4025/actascibiolsci.v38i3.307 51

Sang, N. and Li, G. K. (2004). Genotoxicity of municipal landfill leachate on root tips of Vicia faba. Mutation Research Mutation 
$\begin{array}{lrr}\text { Research/Genetic Toxicology } & \text { and } \\ \text { Environmental Mutagenesis 560 } & \text { 159-165. }\end{array}$ https://doi.org/10.1016/j.mrgentox.2004.02.015

Smaka-Kincl, V., Stegnar, P., Lovka, M. and Toman, M. J. (1996). The evaluation of waste, surface and ground water quality using the Allium Test procedure. Mutation Research/Genetic Toxicology, $\quad 368, \quad 171-179$. https://doi.org/10.1016/s0165-1218(96)90059-2

Souguir, D., Ferjani, E., Ledoigt, G. and Goupil, P. (2008). Exposure of Vicia faba and Pisum sativum to copper-induced genotoxicity. Protoplasma 233, 203-207. https://doi.org/10.1007/s00709-008-0004-9
Tabrez, S., Shakil, S., Urooj, M., Damanhouri, G. A., Abuzenadah, A. M. and Ahmad, M. (2011). Genotoxicity testing and biomarker studies on surface waters: an overview of the techniques and their efficacies. Journal of Environmental Science and Health, Part C, 29, 250-275. https://doi.org/10.1080/10590501.2011.601849

Tedesco, S. B. and Laughinghouse, H. D. (2012). Bioindicator of genotoxicity: The Allium cepa test. Environmental Contamination, 137-156.

Türkoğlu, Ş. (2013). Evaluation of genotoxic effects of five flavour enhancers (glutamates) on the root meristem cells of Allium cepa. Toxicology and Industrial Health, 31(9), 792-801. 